\title{
Erratum to: Results of FLT3 mutation screening and correlations with immunophenotyping in 169 Brazilian patients with acute myeloid leukemia
}

\author{
Antonio R. Lucena-Araujo - Danielle L. Souza - Fabio Morato de Oliveira • \\ Mariana Tereza Lira Benicio • Lorena L. Figueiredo-Pontes • \\ Barbara A. Santana-Lemos • Guilherme A. dos Santos • Rafael H. Jacomo • \\ Anemari R. Dinarte-Santos • Mihoko Yamamoto • Wilson A. Silva-Jr • \\ Maria de Lourdes Chauffaille • Eduardo M. Rego
}

Published online: 18 November 2009

(C) Springer-Verlag 2009

\section{Erratum to: Ann Hematol}

DOI 10.1007/s00277-009-0817-4

The DNA sequences in Figure 1B were presented incorrectly.

The correct version is given on the next page.

The online version of the original article can be found at http://dx.doi. org/10.1007/s00277-009-0817-4.

A. R. Lucena-Araujo • D. L. Souza • F. M. de Oliveira •

M. T. L. Benicio • L. L. Figueiredo-Pontes •

B. A. Santana-Lemos $\cdot$ G. A. dos Santos $\cdot$ R. H. Jacomo $•$

E. M. Rego $(\bowtie)$

Hematology Division, Department of Internal Medicine,

National Institute of Science and Technology on Cell Based

Therapy, Medical School of Ribeirão Preto,

University of São Paulo,

Ribeirão Preto, Brazil

e-mail: emrego@hcrp.fmrp.usp.br

\footnotetext{
A. R. Dinarte-Santos $\cdot$ W. A. Silva-Jr

Department of Genetics, National Institute of Science and Technology on Cell Based Therapy,

Av. Bandeirantes, 3900,

14048-900 Ribeirão Preto, São Paulo, Brazil

M. Yamamoto $\cdot$ M. de Lourdes Chauffaille

Department of Hematology and Hemotherapy,

Federal University of São Paulo,

São Paulo, Brazil
}

Medical School of Ribeirão Preto, University of São Paulo, 
a

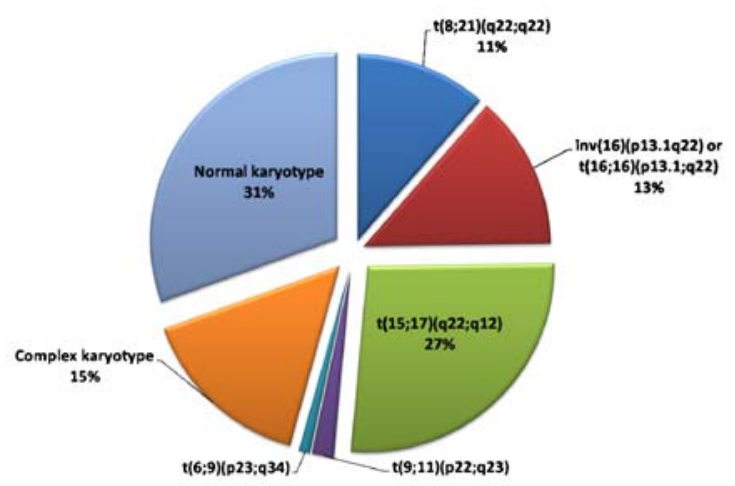

b

AML AML AML AML AML AML AML AML ND CTL Pact 1 Pact 2 Pact 3 Pact 4 NS Pact5 Pact 6 Pact 7 Pact 8

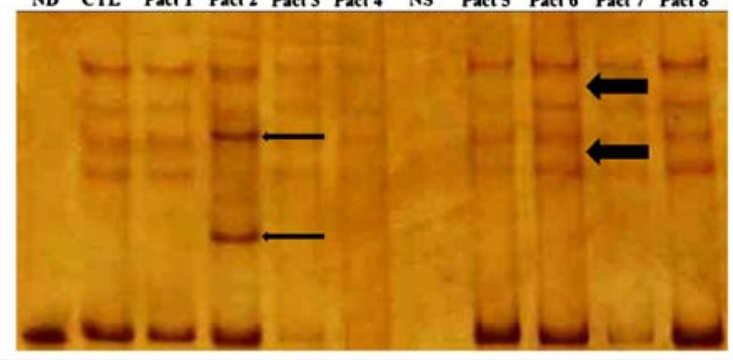

Normal Sequence-exon 20: GGA TTG GCT CGA GAT ATC ATG AGT GAT TCC $G \quad L \quad A \quad R \quad D \quad I \quad M \quad S \quad D \quad S$ Mutated Sequence-exon 20: GGA TTG GCT CGA GAT … ATG AGT GAT TCC

C

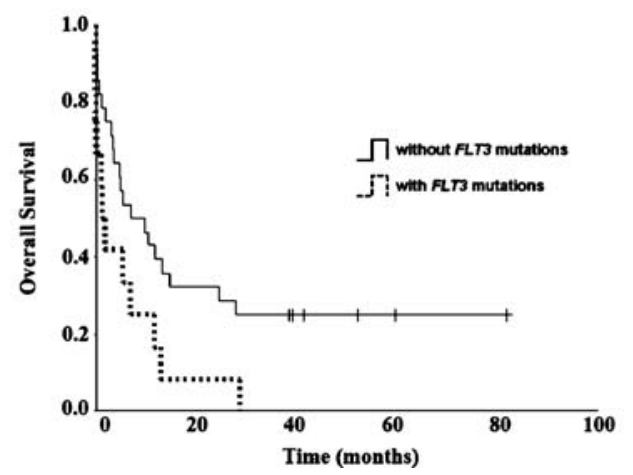

